\title{
International Differences in IFRS Policy Choice and the Persistence of Accounting Classification: The Case of China
}

\author{
Silvia Rossetti ${ }^{1} \&$ Roberto Verona ${ }^{1}$ \\ ${ }^{1}$ University of Pisa, Italy \\ Correspondence: Silvia Rossetti, University of Pisa, Italy. E-mail: s.rossetti@ec.unipi.it
}

Received: October 4, 2016

Accepted: January 20, $2017 \quad$ Online Published: January 26, 2017

doi:10.5539/ijbm.v12n2p27

URL: http://dx.doi.org/10.5539/ijbm.v12n2p27

\begin{abstract}
This paper focuses on the application of IFRS standards in China. The research is mainly conducted on the basis of Kvaal and Nobes's studies (2010) regarding the different ways that various countries apply IFRS and Nobes's IFRS accounting classification system (2011). For companies that issued B shares, the use of IFRS in China lasted only until the 2006 ASBE (Accounting Standards for Business Enterprises) reform. The present study examines IFRS overt options in an attempt to 1) review the choices made by Chinese companies to discover - in light of the applicable PRC GAAP (Chinese Local Standards) requirement of that time - whether they were more or less likely to choose an option than the other countries analysed by Nobes \& Kvaal; 2) rank China's place within Nobes's accounting classification system; and 3) rank China' place, again in the Nobes's model but also in light of a recent study based on BRICS (Note 1)countries (Sarquis, et al. 2014). The results of the statistical analysis confirm that Chinese financial statements display a "local" nature in their use of IFRS and that in its accounting tendencies, China belongs to the Continental European group rather than with the other BRICS countries.
\end{abstract}

Keywords: China, IFRS, policy choice, international accounting, BRICS

\section{Introduction}

\subsection{The Global Challenge of the Accounting}

The aim of accounting - helping the users of accounting information to be aware and informed in their decisions - may be more broadly associated with fulfilling a need for information, in other words, helping others understand the meaning of a message that is sent and/or received, whether numerical or literal. The development of the world economies, their financial markets, and the creation and growth of groups of multinational companies have overcome geographical boundaries, but this process has failed to result in a consistent language. This inconsistency is even greater in the area of economics and business and results in difficulties understanding the financial statements of companies under different jurisdictions despite an increasing need to compare economic-financial information. This situation is more dramatically felt by rapidly expanding economies. Their rapid development, potentially combined with a deeply different or inadequate accounting culture, creates a barrier to those companies that would like to take up the challenge of internationalisation and to those foreign investors who are interested in investing in these countries (Note 2). These factors, briefly summarised, have led China, along with other hyper-developing countries, to thoroughly update its accounting system, while its socialist planned economy moved towards a socialist market economy.

\subsection{Accounting in China}

China is one of the most important emerging economies in the world; its GDP has grown incredibly over the last ten years to put the country in second place, after the US, in terms of nominal GDP (source IMF Outlook 2013). From a historical point of view, 'modern' China only appeared after the Opium War in 1842. However, from an accounting perspective, modern China began with the Open Door Policy reform of 1979, at which point the country opened its doors for the first time to foreign capital, and Deng Xiaoping implemented the initial phase of the Socialist Market Economy. Overviewing China's accounting history also means reviewing the traditions and history of this centuries-old culture. The transition from a dynastic China to a Socialist market economy saw a succession of major historical eras in the country. In particular, in the last twenty years, China has focused its efforts toward developing its own economy while simultaneously becoming increasingly global. In terms of 
accounting, major efforts have been made; in particular from 1992, when the first ASBE (Note 3) was launched, until 2006, when the new PRC GAAP (Note 4) matched, albeit indirectly, the IAS/IFRS international accounting standards. These reforms have also brought positive changes to the study of accounting and attracted the interest of Western scholars, which would have been unimaginable and unfeasible a few decades ago. The adoption of IFRS accounting standards by many countries has dramatically changed the international accounting world and the related studies. IFRS standards aim to standardise the accounting language for companies under different jurisdictions, thus overcoming the localisms resulting from national GAAPs. In spite of this goal, some studies highlighted the persistence of differing practices in countries that have applied IFRS (Kvaal \& Nobes, 2010, 2012; Nobes, 2006, 2011, 2013; Nobes \& Stadler, 2013; Stadler \& Nobes, 2014). This latter research focuses on the IFRS policy choices reflected in financial statements and attempts to determine similarities and differences in how countries apply IFRS. This type of analysis notes a tendency toward methodical behaviour in financial statement preparation with respect to either IFRS or to policy choices common in the local GAAP (Kvaal \& Nobes, 2010, 2012). These studies highlighted how some specific characteristics keep coming to the fore in connection with primary regions localised in past studies, i.e., the Anglo-Saxon and the Continental European countries (Nobes, 2011, 2013). Addressing China, within this latter type of research, the most important study was conducted by Nobes \& Stadler in 2013 on Chinese companies listed on the Hong Kong Stock Exchange. This research identifies similarities between the use of IFRS by Chinese companies and that by Anglo Saxon countries. As stated by the authors, these results can be interpreted based on the influence exercised by the UK through Hong Kong (called the "colonialism effect"). In the present study, the analysed companies are listed on the Chinese Mainland Exchange (Shanghai and Shenzhen). These financial statements are prepared according to Chinese rules that were (and are) deeply different from those in Hong Kong. Until 2007, Chinese companies that issued shares purchasable by foreign investors were required to prepare their financial statements using PRC GAAP (Note 5) and IFRS (Note 6). Thus, they were required to use two different types of accounting standards for the same year. The analysis of IFRS policy choice in China represents a new contribution to the international accounting literature and an extension to the prior analysis focused on other countries applying IFRS. This research also aims to contribute, given the position of China, to the international classification proposed by Nobes in 2011 based on the well-known dualism between Continental European and Anglo-Saxon countries.

\subsection{Relevant Scholarship}

The modern age of China's accounting practices begins with the reforms first implemented by Deng Xiaoping in 1978. The innovative scope of these reforms lies in the formal adoption of the double-entry method as well as in the start of a gradual decrease in the central role of the State as the sole user of accounting records. Even if the State continues to play a key role in the development of accounting methods as a law-making institution and as the issuer of accounting principles, China has made huge efforts to internationalise its accounting practices. The most powerful initiative was the issuance of the first Accounting Standards for Business Enterprises (ASBE) in 1992, followed by three further reforms, in 1998, 2001 and 2006. The issuance of the ASBE, as part of the opening up to foreign capital in 1978, was the most important step. We could call this "year zero" in China's accounting practices because it brought a common conceptual framework to a highly fragmented accounting system as a type of "guideline" for any company.

In the literature, the conceptual framework brought in by the ASBE has been defined (Xiao and Pan 1995) as "mixed", i.e., descriptive, prescriptive and constitutive. Despite the major efforts made by the Chinese authorities to borrow its content from the IASB, it is still markedly different. Empirical research into the extent of harmonisation between the PRC GAAP and the IFRS principles based on Chinese companies' financial statements found remarkable differences, which were gradually reduced by the reforms of 1998 and 2001 (Chen et al., 1999, Lin \& Wang 2001, Chen et al., 2002, Lin and Chen 2005, Peng et al., 2008, Foo et al., 2009, Chen \& Zhang, 2010, Olesen \& Cheng 2011). The support of international organisations, such as the World Bank, China's accession to the WTO (2001) and the development of China's stock markets (Shanghai and Shenzhen) played key roles in driving China to give its standards an increasingly international outlook. This process was formally ended in 2006, the year the new Accounting Standards for Business Enterprises were issued. With the issuance of the new ASBE, the IASB also thought that the harmonisation process had concluded, suggesting that the PRC GAAP substantially converged with IFRS principles (Note 7).

Currently, in China, the accounting principles used by all companies are the PRC GAAP, while the IFRS principles cannot be applied. The application of IFRS principles in China was compulsory until 2006, but only for the financial statements of those companies that issued B shares, i.e., shares that can be bought by foreign investors (Note 8). After the 2006 accounting reform, this restriction lapsed, and the companies that issued B shares were no longer obliged to draw up their financial statements on the basis of IFRS international principles. 
A review of the process through which China came to meet the IFRS standards along with the other hyper-developing economies, or better, the BRICS (Brazil, Russia, India, China and South Africa), shows that China's journey and targets are similar to those of India, which continued using local GAAP as an accounting standard (Indian Accounting Standards-IndASs). Russia, Brazil and South Africa have instead slowly completed their formal adherence to IFRS standards (Note 9), therefore establishing their distance from China and India.

China's choice reflects the Chinese Government's will to remain independent when making decisions about its accounting methods. This can be more easily understood if we consider the following dimensions of the Chinese economy, which already existed as early as the first reform of 1992 and which still exist, although to a lesser extent:

1) The majority of Chinese companies were, and partly are, owned by the State.

2) The primary user of accounting records, despite the reforms, was still the State.

3) Companies listed on the Mainland China stock exchanges, i.e., Shenzhen and Shanghai, could (and still can) only be Chinese companies; in other words, foreign companies cannot be listed (but they may be listed on the Hong Kong Stock Exchange).

Although China's "IFRS experience" lasted until the end of 2006, the same cannot be said of a large part of the world because such principles are currently used in over one hundred countries. In this respect, we could say that the efforts made by IASB since 1973, the year the conceptual framework was issued, to achieve harmonization of accounting standards, are proving to be effective. However, the emerging countries, those with the highest economic growth rates, are having more trouble harmonising their accounting languages with the rest of the world because exponential economic growth does not often go hand in hand with growth in the accounting culture and infrastructure (e.g., financial markets).

The adoption, albeit for a period of time, of the IFRS by Chinese companies is an opportunity to contribute to the international accounting studies that address differences between countries despite the harmonisation of accounting principles based on the IFRS. We refer to the studies conducted by Nobes $(2006,2011,2013)$ and Kvaal and Nobes $(2010,2012)$, which examine the choices made by such countries when issuing their financial statements in terms of overt options in the IFRS.

The major differences between countries' accounting languages stem from a number of factors ranging from the country's language (Choi \& Mueller, 1992, Walton et al., 1998), to its culture, to its economic and social development (Walton et al., 1998), to the influence of its legal and cultural systems or even to the extent of business activities (Choi \& Mueller, 1992). The wide range of accounting languages that can be found on the global scene or, as it has been called, "Tower of Babel accounting" (Erikson et al. 2009), is the starting point for any international accounting study.

Nobes $(1981,1983)$ found that the weaknesses of the ranking studies conducted prior to the 1980 s were as follows: fairly inaccurate in defining the ranked items; no statistical models to compare the figures; no hierarchy between ranks; and no explanations for choosing the so-called "major features". Therefore, taking his cue from Mueller's micro and macro areas $(1967)$, Nobes $(1981,1983)$ developed a hierarchical model based on the ranks of natural science in an attempt to understand variations between groups. Eventually, he came up with two macro areas:

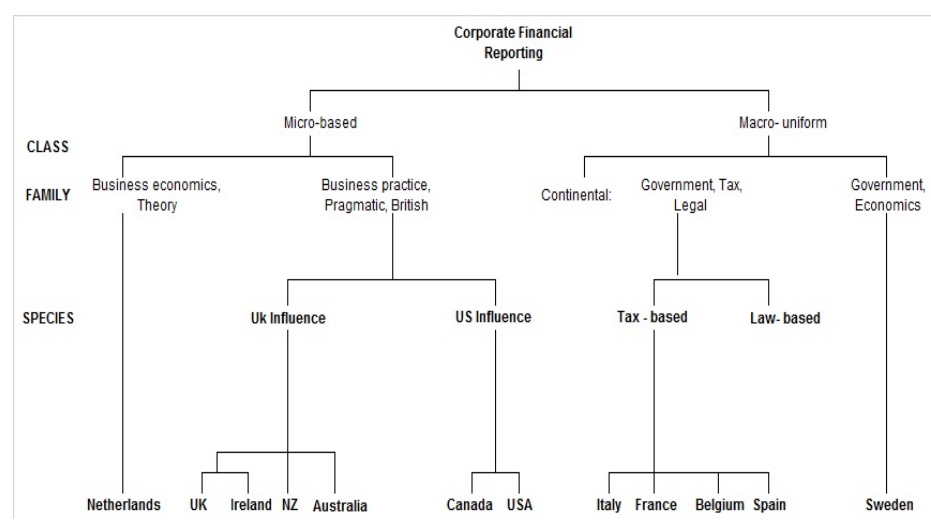

Figure 1. A hypothetical classification of financial reporting measurement practices in developed western countries in 1980 (Nobes, 1983) 
Subsequently, Nobes's studies (1998) became increasingly focused on financial reporting in an attempt, according to the author, to clarify the ranked items and to develop a general theory that could connect all potential discriminating factors (Note 10). In this respect, ranking focused on the Anglo-Saxon and Continental European areas, which had two different types of financial systems (described by Zysman in 1983), i.e., Insider Dominant and Outsider Dominant, depending on the relationship between the investor and the investment object. In Nobes's model, this approach was crossbred with the country's cultural model, making a distinction between "dominant countries" and "dominated countries", i.e., countries that have independently developed their own culture and countries that have been influenced by these dominant countries. In Outsider Dominant countries, accounting serves an informational purpose for the shareholders, while in Insider Dominant countries; the informational role of accounting is more often addressed to financial managers and creditors. In addition, Nobes developed a migration model based on the evolution of a company's financial system and/or financial decisions regarding internationalisation. Countries that presented the characteristics defined as Class A belong to the Anglo group, while countries within Class B are closer to the European Continental group (Nobes, 1998, 2011). In such international accounting studies, China's position cannot be determined. As mentioned earlier, the country's rejection of the western world, economic backwardness and poor use of the English language, as well as its totally different approach to accounting, made it extremely difficult for foreign scholars (Chen and Tran 1995) to obtain a full understanding of the accounting methods used in China. Of the above studies, the first that reviews China's "position", albeit indirectly, is Mueller's study (1968). This study is based on four features, economic development, complexity of trade, influence of the public sector, and legal systems, and includes the "Communist Nations". After Muller, Communist countries were also included in ranking studies by the American Accounting Association, which added these countries to its definition of the Accounting Zone of Influence. Both approaches to categorizing these countries are based on historical, economic and cultural grounds. Because of their unique differences from market economies, the Communist countries were certainly easily distinguishable in such "pioneering" studies (Di Pietra, 2000).

As we mentioned earlier, ranking studies have been outnumbered by works that analyse the development of China's accounting system and its harmonisation with IFRS through the four stages of China's reform of its ASBE in 1992, 1998, 2001 and, finally, 2006. The enforcement of the IFRS in many countries across the world was a major step in the standardisation of accounting practices. However, the idea that standards translate into perfectly standardised financial reports is considered to be a naïve concept (Ball 2006) because the political, economic, financial and legal aspects, as well as the accounting traditions, of each country (Nobes 2006) influence the financial preparers.

Nobes (2006) identified some elements that contribute to such continuing differences between countries, despite the enforcement of IFRS principles; these are different versions of the IFRS, gaps in the IFRS, different translations of the IFRS, covert options and vague criteria, estimations in the IFRS, transitional or first-time adoption issues, imperfect enforcement of the IFRS and overt options.

The overt options, and therefore the financial preparers' freedom, may be a bridge that connects the national GAAP with the IFRS (Kvaal \& Nobes, 2010, 2012), leading to differences between countries as well as emphasising common features (Nobes, 2011). The IFRS overt options are the result of the many parties involved in the discussion of standards and the influence they exert; even if these options have been remarkably reduced by the publication of the IASB framework, they still exist.

The research conducted by Kvaal and Nobes (2010) found a relation between companies' choice of overt IFRS options and their national principles. This relation exists because preparers are still local. In this sense, a country's legal and financial system still drives the different ways of using the IFRS, so we can still separate an Anglo group and a Continental European group despite the level of standardisation resulting from the IFRS (Nobes, 2011).

As mentioned by Nobes (1998), because of its legal and financial system, China is in class B, i.e., it is one of those countries with a weak or immature financial market where the role of accounting goes hand in hand with taxation. In China, this is more deeply felt because of the central role played by the State as a standard setter as well as an entrepreneur, with SOEs controlling many of the country's business industries. Despite being in class B, as mentioned by Nobes $(1998,2011)$, China is making efforts, at least with its listed companies, to move to class A. These efforts were empirically substantiated by Nobes and Stadler (2013) when they reviewed the policy options of Chinese companies listed on the Hong Kong Stock Exchange. Multidimensional scaling found a remarkable similarity between companies from Hong Kong, the UK and China. The author commented that the result may be an effect of colonialism, given the British influence until 1997. 


\section{Contribution to the literature}

This paper aims to contribute to the literature in three different ways:

1) It represents the first time that the IFRS policy options of Chinese companies listed on Mainland China's Stock Exchanges have been reviewed on the basis of the local principles and compared with the choices made by other countries.

2) China is classed within Nobes's classification system (1998) in an attempt to discover whether it still is an "A" country despite the enforcement of the IFRS. Such classification has never been addressed by the literature except for Chinese companies listed on the Hong Kong Stock Exchange (Nobes \& Stadler 2013).

3) The review of China's accounting practices, in terms of IFRS policy options when Chinese companies had to meet such a requirement, is an interesting perspective for later studies on the elements of the PRC GAAP (Note 12) that have substantially converged with the IFRS. In addition, the accounting reports covered by this paper concern the last few years in which the IFRS was still in force; this is thus another perspective for later studies that might also address changes in policies in light of the 2006 ASBE reform.

\section{Method}

The goal of this paper is to review the enforcement of the IFRS principles in China when they are used by Chinese companies listed on the Mainland Chinese Stock Exchanges.

The purposes of this paper are as follows:

OB. 1: Examine the choices made by Chinese companies when enforcing IFRS in terms of the existing overt IFRS options while also considering the current prescriptions of local GAAP. Further, analyse China's choices compared with 5 other countries (UK, Australia, Germany, France and Spain) using binomial tests, as addressed by Kvaal \& Nobes (2010).

OB. 2: Classify China within Nobes's international classification of IFRS countries.

OB. 3: Compare China's classification with the other BRICS countries addressed by Sarquis et al., (2014).

Relative to objective 1, we can observe that the analysis of Kvaal \& Nobes directly checked IFRS policy choice for the first year of adoption. The hypothesis within this study considers methodical behaviour from financial statement preparers as permitted by IFRS policy choice, that is, preserving those procedures and methods already known from their local GAAP and now included in the IFRS policy.

Considering the Chinese sample, we must note that we do not consider the first year of adoption of IFRS. However, the situation is the same as for those countries analysed by Kvaal \& Nobes because those countries were obliged to draw up their financial statements under either IFRS or local GAAP. In this sense, the base hypothesis defined by Kvaal \& Nobes for their sample, effective for only the first year of IFRS adoption, works in China, where two different sets of principles were in use for companies that issued A and B shares until 2007.

To achieve these objectives, we conducted the following statistical analyses:

a) Descriptive statistical analysis

b) Hypothesis testing based on a chi-square test and a pairwise binomial test

a) Multivariate analysis (principal component analysis, multidimensional scaling, cluster analysis)

\subsection{Participant Characteristics}

The Chinese companies listed in the Mainland Chinese Stock Exchange (Shanghai and Shenzhen) could issue two types of shares:

- A shares, purchasable only by Chinese citizens

- B shares, purchasable by foreign investors

Companies could decide to issue either type of share. Before the last ASBE reform (2006), the rules for financial statements were as follows:

1. Companies issuing A shares must fulfil their financial statements under the PRC GAAP

2. Companies issuing B shares must fulfil their financial statements under IFRS

3. Companies issuing A shares and B shares must fulfil their financial statements under PRC GAAP and IFRS (two different type of financial statements).

For the Chinese companies under points 2) and 3), the requirement regarding IFRS was in force until 2007. After 
that time, all Chinese companies listed on the Mainland Chinese Stock Exchange were required to draw up their financial statements under the new PRC GAAP, which the IASB considered to have substantially converged with IFRS. Therefore, the use of IFRS is no longer required (and in fact not allowed).

\subsection{Sampling Procedures and Sample Size}

This paper reviews the policy choices made in the financial statements of Chinese companies listed on the Shanghai and Shenzhen Stock Exchanges in 2005/2006, i.e., the last years such companies had to fulfil the IFRS requirement.

In total, 52 companies listed on the Shenzhen Stock Exchange and 53 companies listed on the Shanghai Stock Exchange issued B shares (B shares only or B and A shares together). Out of the total number of companies that could be surveyed (105), only 43 could provide reports in English for the years investigated (2005/2006). A total of $79 \%$ of surveyed companies are listed on the Shenzhen Stock Exchange; the remainder are listed on the Shanghai Stock Exchange. The total proportion of sampled companies that issue both A and B shares is $88 \%$. As shown in the table 1, industry and consumer goods are the most representative industries. There are no financial companies in the surveyed sample because there are no financial companies issuing B shares for the years analysed. This aspect, unfortunately, represents a weakness in the surveyed sample because the presence of financial firms could affect the comparability in some of the choices investigated for China (Operating cash flow, PPE and Investment property) with respect to the data collected by Kvaal \& Nobes - for Australia and the UK in particular - in which financial firms are present in good number (Nobes \& Stadler 2013, Stadler \& Nobes 2014). The purpose of these analyses was to test China's position within the classification system on the assumption that China is closer to the Continental European group. This analysis was conducted using the sample in Nobes (2011) referring to Australia, the UK, Germany, France, Spain, Holland, Italy and Sweden. We also considered the data collected by Sarquis et al. for Brazil, Russia and South Africa using the leading companies on the Bovespa Index, MICEX-RTS, and FTSE/JSE top 40 Index, respectively

Table 1. China sector distribution

\begin{tabular}{lll}
\hline & Sector Distribution & $\begin{array}{l}\text { Number } \\
\text { companies }\end{array}$ \\
\hline $\mathbf{0}$ & Oil and gas & 1 \\
$\mathbf{1}$ & Basic materials & 3 \\
$\mathbf{2}$ & Industrials & 17 \\
$\mathbf{3}$ & Consumer goods & 9 \\
$\mathbf{4}$ & Health care & 1 \\
$\mathbf{5}$ & Consumer services & 7 \\
$\mathbf{6}$ & Telecommunications & 1 \\
$\mathbf{7}$ & Utilities & 2 \\
$\mathbf{8}$ & Financials & 0 \\
$\mathbf{9}$ & Thechnology & 2 \\
& Total & $\mathbf{4 3}$ \\
\hline
\end{tabular}

\subsection{Research Design}

A total of 16 IFRS policy choices were presented at the time of our analysis. The policy choices considered for the analysis were as follows:

1) Descriptive statistical analysis: all 16 IFRS policy choices were analysed;

2) Hypothesis test: 10 IFRS policy choices were analysed. We considered only the IFRS principles that have a correspondent in the Chinese local GAAP;

3) Multivariate analysis: 13 IFRS policy choices. We considered the same IFRS policies analysed by Nobes in 2011 because our sample is formed with the data collected by Nobes in 2011 (and also by Sarquis et al. for three BRICS countries).

The following table presents all 16 policy choices and the corresponding principles in the PRC GAAP. 
Table 2. Comparison between IFRS overt options and PRC GAAP

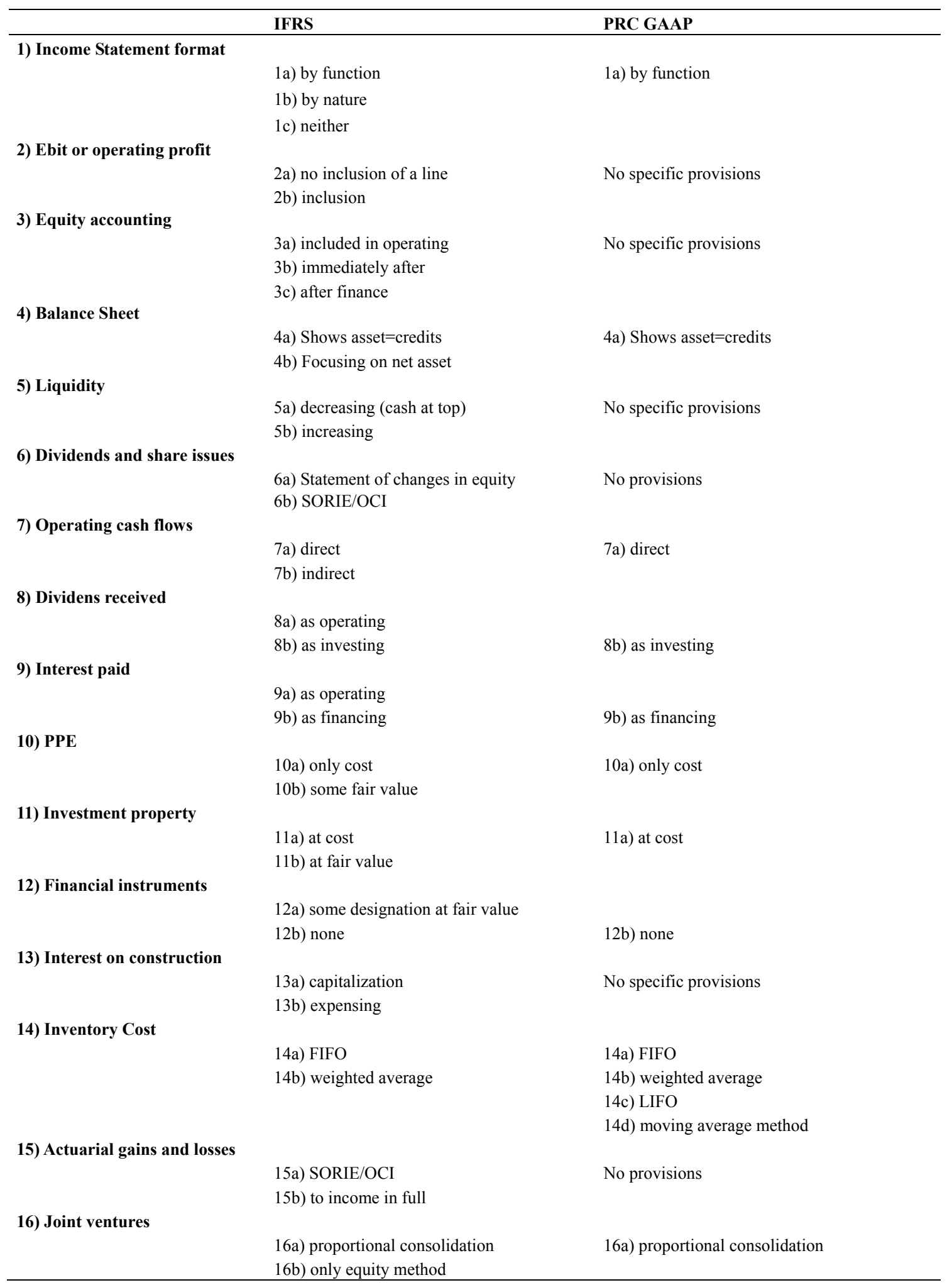

The data collected for the descriptive statistical analysis and binomial tests are in the following table: 
Table 3. Policy choices (\% of companies by countries): Data from Kvaal \& Nobes (2010) and our collection of data for China

\begin{tabular}{|c|c|c|c|c|c|c|}
\hline \multirow[t]{2}{*}{ IFRS Policy Choice } & \multicolumn{5}{|c|}{ Kvaal and Nobes (2010) } & \multirow{2}{*}{$\begin{array}{l}\text { Our data } \\
\text { Chn }\end{array}$} \\
\hline & Aus & U.K. & France & Spain & Germ & \\
\hline Income statement by function & 59,3 & 47,2 & 54,8 & 4 & 76,5 & 86,05 \\
\hline Focusing on net assets & 100 & 84,7 & & 0 & 0 & 18,6 \\
\hline Indirect cash flows & 0 & 98 & 100 & 87,5 & 100 & 51,16 \\
\hline Dividend received as operating & 87,5 & 36,7 & 92,9 & 50 & 66,7 & 45,15 \\
\hline Interest paid as operating flow & 90,9 & 68,4 & 88,6 & 38,7 & 61,9 & 78,38 \\
\hline Some PPE at fair value & 13,6 & 12,2 & 0 & 0 & 0 & 4,65 \\
\hline Investment property at fair value & 42,9 & 73,1 & 0 & 0 & 0 & 9,09 \\
\hline Some fair value designation & 29,6 & 12,5 & 32,3 & 12 & 5,9 & 39,02 \\
\hline Weighted average only & 59,1 & 29,2 & 57,7 & 88,2 & 71,4 & 92,5 \\
\hline Proportional consolidation & 5,3 & 22,4 & 81,3 & 84,6 & 31,3 & 50 \\
\hline Inclusion of a line for EBIT or op profit & 51,9 & 97,2 & 100 & 96 & 100 & 74,42 \\
\hline Equity accounting in operating & 63,2 & 24,5 & 6,9 & 0 & 18,8 & 5,56 \\
\hline Liquidity Increasing & 0 & 100 & 100 & 96,3 & 85 & 95,35 \\
\hline SORIE/OCI only & 65,9 & 83,7 & 5,7 & 25 & 21,7 & 0 \\
\hline Interest capitalization & 75,8 & 47,5 & 40 & 94,4 & 22,2 & 92,11 \\
\hline Actuarial gains/losses to SORIE & 72,7 & 84,4 & 20 & 12,5 & 47,6 & 0 \\
\hline
\end{tabular}

The data analysed (policy choices) for the multivariate analysis are as follows:

Table 4. Policy choices (\% of companies by countries): Data from Nobes (2011), Sarquis et al. (2014) and our collection of data for China

\begin{tabular}{|c|c|c|c|c|c|c|c|c|c|c|c|c|c|}
\hline \multirow{4}{*}{1} & & \multicolumn{7}{|c|}{ Nobes 2011} & & \multicolumn{3}{|c|}{ Sarquis et al. 2014} & \multirow{2}{*}{$\begin{array}{l}\text { Our data } \\
\text { Chn }\end{array}$} \\
\hline & & Aus & U.K. & France & Spain & Germ & Netherlands & Italy & Sweden & Brazil & Russia & South Africa & \\
\hline & Income statement by & & & & & & & & & & & & \\
\hline & function & 58,3 & 82,1 & 62,1 & 4,8 & 82,6 & 50 & 7,1 & 95 & 96,2 & 66,7 & 83,3 & 86,05 \\
\hline 2 & Equity acc in operating & 68,8 & 42,6 & 10 & 0 & 22,7 & 0 & 0 & 93,3 & 83,7 & 45,8 & 26,3 & 5,56 \\
\hline 3 & Focusing on net assets & 100 & 85,2 & 0 & 0 & 0 & 14,3 & 0 & 0 & 0 & 0 & 8,3 & 18,6 \\
\hline 4 & SORIE/OCI only & 0 & 0 & 0 & 0 & 0 & 0 & 0 & 0 & 0 & 0 & 0 & 0 \\
\hline 5 & Indirect cash flows & 8,3 & 100 & 100 & 87,5 & 100 & 100 & 100 & 100 & 100 & 93,3 & 66,7 & 51,16 \\
\hline \multirow[t]{2}{*}{6} & Interest paid & & & & & & & & & & & & 78,38 \\
\hline & operating flow & 81,5 & 65,1 & 80 & 47,6 & 68,2 & 78,5 & 92,9 & 90 & 77,4 & 53,3 & 87,5 & \\
\hline 7 & Some PPE at fair value & 15 & 11,1 & 0 & 0 & 0 & 11,8 & 0 & 3,8 & 0 & 5,9 & 3 & 4,65 \\
\hline \multirow[t]{2}{*}{8} & Investment property at & & & & & & & & & & & & 9,09 \\
\hline & fair value & 39,3 & 70,8 & 14,3 & 13,3 & 5,3 & 75 & 5,6 & 100 & 28,6 & 55,6 & 58,3 & \\
\hline \multirow[t]{2}{*}{9} & Some fair value & & & & & & & & & & & & 39,02 \\
\hline & designation & 25 & 11,1 & 33,3 & 19 & 17,4 & 75 & 12,5 & 52,6 & 75 & 87,5 & 80 & \\
\hline 10 & Interest capitalization & 84,4 & 57,7 & 44,4 & 100 & 41,7 & 66,6 & 27,8 & 33,3 & 0 & 0 & 0 & 92,11 \\
\hline 11 & Weighted average only & 52,9 & 30 & 75 & 50 & 88,2 & 41,7 & 78,6 & 10 & 100 & 83,3 & 64,3 & 92,5 \\
\hline \multirow[t]{3}{*}{12} & Actuarial gains/losses to & & & & & & & & & & & & \\
\hline & SORIE & & & & & & & & & & & & \\
\hline & & 86,7 & 86,4 & 50 & 63,2 & 63,3 & 31,3 & 20,8 & 20 & 50 & 33,3 & 37,5 & 0 \\
\hline \multirow[t]{2}{*}{13} & Proportional & & & & & & & & & & & & \\
\hline & consolidation & 11,5 & 23,3 & 75,8 & 91,3 & 15,8 & 46 & 39,1 & 33,3 & 79,6 & 20 & 52 & 50 \\
\hline
\end{tabular}

\section{Results}

This paper addresses the results of the analyses as they pertain to its stated goals in the following sections. 


\subsection{Descriptive Analysis}

The first goal was achieved by examining which IFRS policies most frequently used descriptive statistics (Fig. 2 and Fig. 3). This first descriptive analysis can suggest whether the Chinese companies, in choosing between options, opted more frequently for a method that they already used and that was similar to the PRC GAAP.

The descriptive analysis of results can be briefly divided into two key areas based on policy options: one related to the presentation of financial statements (IAS 1; IAS 7 in Fig. 2) and the other to measurement topics (IAS 16; IAS 40; IAS 39; IAS 2; IAS 19; IAS 31 in Fig. 3). Some assumptions have not been addressed at this stage because deviation in the frequency of such assumptions was less than $10 \%$, which means that the sample is evenly distributed, with no assumption clearly prevailing over the other. Looking first at the chosen presentation methods (Fig. 2), virtually all companies in the sample opted for the following choices:

- Income statement format: $86.05 \%$ of the sample chose to record their expenses by function $(\mathrm{N}=43)$.

- Inclusion of a line for EBIT or operating profit: $74.42 \%$ of the sample chose to show their operating profits $(\mathrm{N}=43)$.

- Balance sheet showing net assets or not: net assets not included in $81.40 \%$ of the balance sheets $(\mathrm{N}=43)$.

- Order of liquidity in balance sheets: $95.35 \%$ of the sample chose a liquidity-increasing method $(\mathrm{N}=43)$.

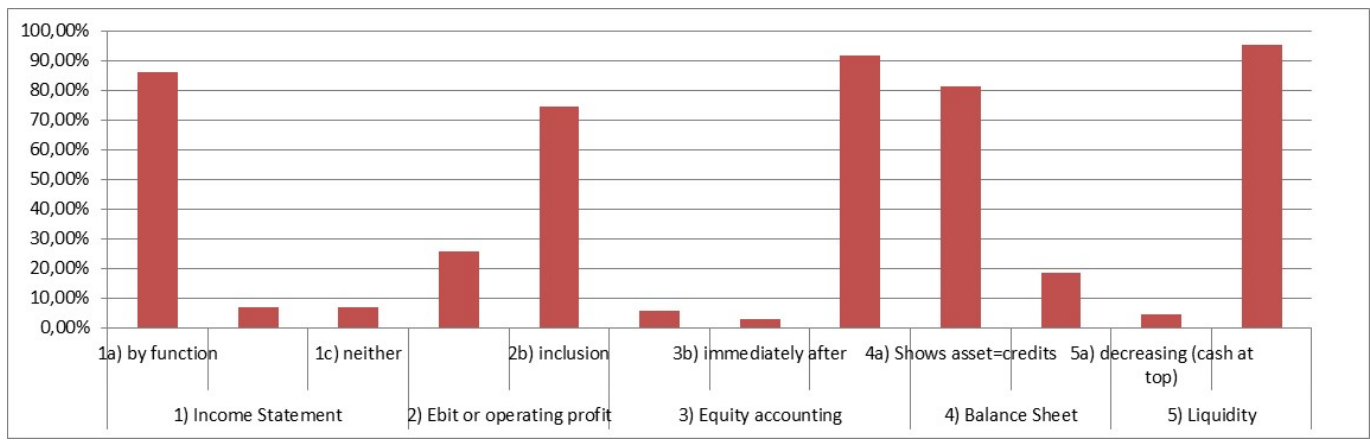

Figure 2. Presentation of financial statements: Chinese companies' policy choices

Considering PRC GAAP, the \% of Chinese companies that preferred, under IFRS enforcement, to use similar methods (\% over $60 \%$ ) to present their financial statements is $100 \%$.

Related to the measurement methods (Fig. 3), we found the following:

- $\quad$ PPE at fair value or not: $95 \%$ of the sample used a cost-based method $(\mathrm{N}=43)$.

- Investment property at fair value or not: $90 \%$ of the sample $(\mathrm{N}=22)$ used a cost-based method.

- Inventory valuation: $92.50 \%$ of the sample $(\mathrm{N}=40)$ used a weighted-average method.

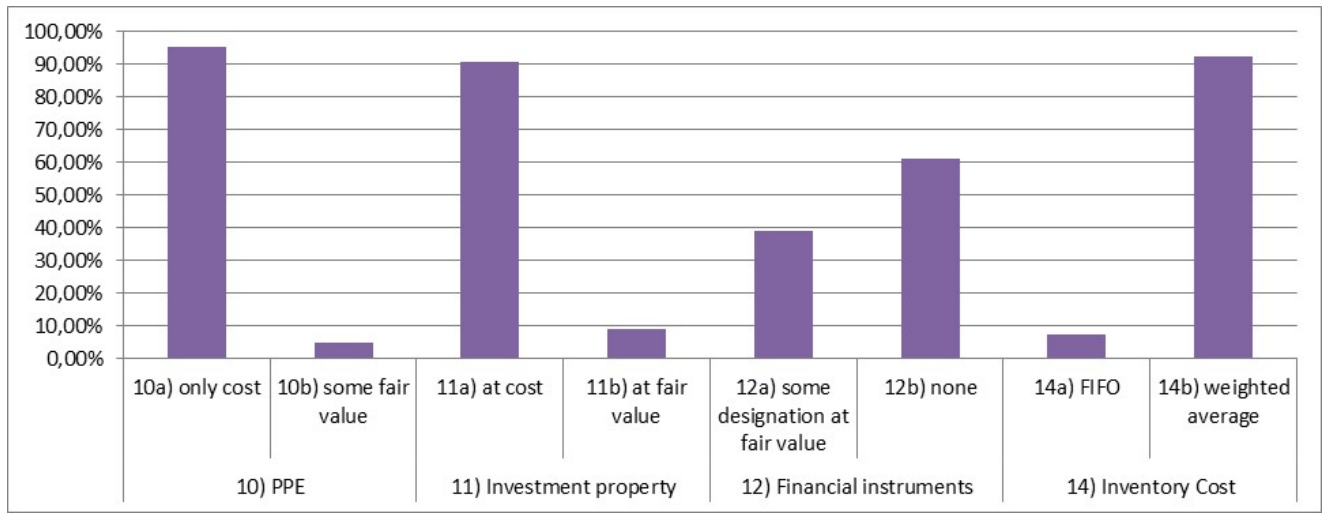

Figure 3. Measurement topics: Chinese companies' policy choices 
Considering Chinese local GAAP, $100 \%$ of Chinese companies applied, under IFRS enforcement, similar methods to evaluate their assets.

In general, considering all of the policies investigated, in only two cases could we observe differences from the prescriptions of PRC GAAP under 50\%. Those cases are related to the cash flow statement.

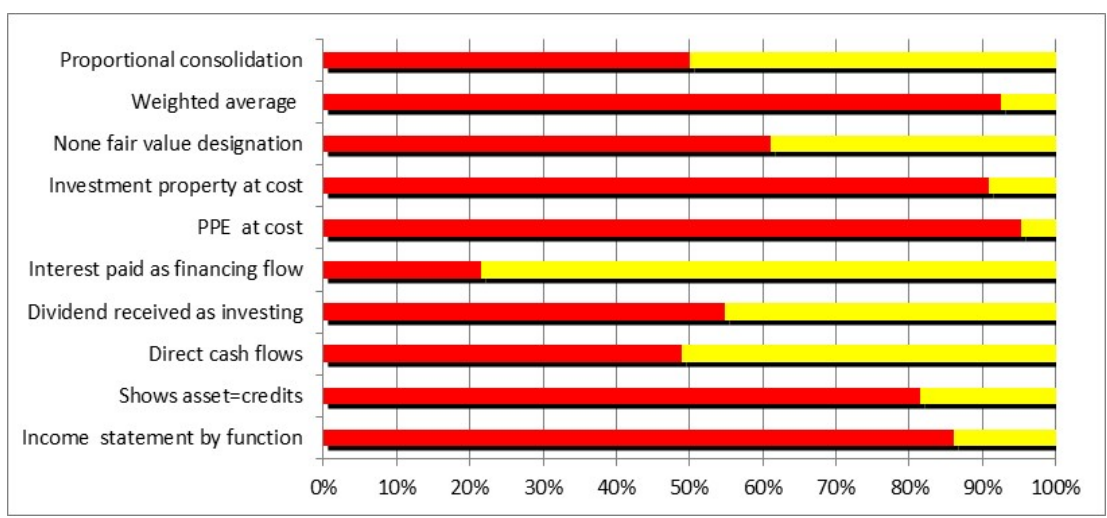

Figure 4. Chinese companies: IFRS policy choices versus PRC GAAP prescriptions

\subsection{Hypothesis Test}

The second step in this review involved a hypothesis test based on two indicators: a chi-square test to measure the overall independence between policy choices and countries for each of the considered issues using Cramer's $\mathrm{V}$ (a value between 0 and 1) and a pairwise binomial test to compare the scores (percentage of companies that apply the policy) of China with those of the other countries. The tested hypotheses aimed to discover whether China differs somehow from the countries tested by Kvaal \& Nobes (Australia, UK, France, Germany and Spain) in terms of local requirements. The policy choices analysed in the pairwise binomial tests are in Table 5.

Table 5. Policy choices (\% of companies by countries) - data from Kvaal \& Nobes (2010) and our collection of data for China

\begin{tabular}{|c|c|c|c|c|c|c|c|c|}
\hline \multirow{2}{*}{\multicolumn{3}{|c|}{$\begin{array}{l}\text { IFRS Policy Choice } \\
\%\end{array}$}} & \multicolumn{5}{|c|}{ Kvaal and Nobes (2010) } & \multirow{2}{*}{$\begin{array}{l}\text { Our data } \\
\text { Chn }\end{array}$} \\
\hline & & & Aus & U.K. & France & Spain & Germ & \\
\hline 1 & (a) & Income statement by function & 59,3 & 47,2 & 54,8 & 4 & 76,5 & 86,05 \\
\hline 2 & (b) & Focusing on net assets & 100 & 84,7 & 0 & 0 & 0 & 18,6 \\
\hline 3 & (b) & Indirect cash flows & 0 & 98 & 100 & 87,5 & 100 & 51,16 \\
\hline 4 & (a) & Dividend received as operating & 87,5 & 36,7 & 92,9 & 50 & 66,7 & 45,15 \\
\hline 5 & (a) & Interest paid as operating flow & 90,9 & 68,4 & 88,6 & 38,7 & 61,9 & 78,38 \\
\hline 6 & (b) & Some PPE at fair value & 13,6 & 12,2 & 0 & 0 & 0 & 4,65 \\
\hline 7 & (b) & Investment property at fair value & 42,9 & 73,1 & 0 & 0 & 0 & 9,09 \\
\hline 8 & (a) & Some fair value designation & 29,6 & 12,5 & 32,3 & 12 & 5,9 & 39,02 \\
\hline 9 & (b) & Weighted average only & 59,1 & 29,2 & 57,7 & 88,2 & 71,4 & 92,5 \\
\hline 10 & (a) & Proportional consolidation & 5,3 & 22,4 & 81,3 & 84,6 & 31,3 & 50 \\
\hline
\end{tabular}

The hypothesis was tested through two different statistical tests: the chi-square test and the binomial test.

- The chi-square test: measures the overall independence between policy choice and country for each considered item using Cramer's V (ranging between 0 and 1);

- The pairwise binomial test: compares the scores (percentage of companies that use a specific policy) of China with those of the other countries, i.e., a total of five tests per policy, leading to 50 binomial tests. For each row, the associated p-value refers to the highest rejection of a given hypothesis among all pairs. 
Table 6 . Policy choices (\% of companies by countries)-chi-square test and the binomial test

\begin{tabular}{|c|c|c|c|c|c|c|c|c|c|c|c|}
\hline \multirow[b]{2}{*}{$\mathbf{N}$} & \multirow[b]{2}{*}{ Policy } & \multicolumn{6}{|c|}{ Country } & \multicolumn{2}{|c|}{ Chi-square test } & \multicolumn{2}{|c|}{ Hypothesis testing (pair-wise) } \\
\hline & & $\begin{array}{l}\text { Chin } \\
\text { a }\end{array}$ & Aus & U.K & $\begin{array}{l}\text { Franc } \\
\mathrm{e}\end{array}$ & $\begin{array}{l}\text { Spai } \\
\mathrm{n}\end{array}$ & $\begin{array}{l}\text { Ger } \\
\mathrm{m}\end{array}$ & $\begin{array}{l}\text { Cramer } \\
\text { V }\end{array}$ & $\begin{array}{l}\text { p-valu } \\
\text { e }\end{array}$ & Null hypothesis & $\begin{array}{l}\text { p-valu } \\
\text { e }\end{array}$ \\
\hline 1 & Income statement by function & 86,1 & 59,3 & 47,2 & 54,8 & 4,0 & 76,5 & 0,473 & 0,000 & Chn > Aus, UK, Fr, Sp & 0,010 \\
\hline 2 & Focusing on net assets & 18,6 & $\begin{array}{l}100 \\
0\end{array}$ & 84,7 & 0,0 & 0,0 & 0,0 & 0,838 & 0,000 & Chn $<$ Aus, UK & 0,000 \\
\hline 3 & Indirect cash flows & 51,2 & 0,0 & 98,0 & 100,0 & 87,5 & 100,0 & 0,832 & 0,000 & Chn $>$ Aus & 0,000 \\
\hline 4 & Dividend received as operating & 45,2 & 87,5 & 36,7 & 92,9 & 50,0 & 66,7 & 0,482 & 0,000 & Chn $<$ Aus, Fr & 0,000 \\
\hline 5 & Interest paid as operating flow & 78,4 & 90,9 & 68,4 & 88,6 & 38,7 & 61,9 & 0,348 & 0,000 & Chn $<$ Aus & 0,100 \\
\hline 6 & Some PPE at fair value & 4,7 & 13,6 & 12,2 & 0,0 & 0,0 & 0,0 & 0,224 & 0,017 & Chn $<$ Aus, UK & 0,100 \\
\hline 7 & Investment property at fair value & 9,1 & 42,9 & 73,1 & 0,0 & 0,0 & 0,0 & 0,638 & 0,000 & Chn $<$ Aus, UK & 0,010 \\
\hline 8 & Some fair value designation & 39,0 & 29,6 & 12,5 & 32,3 & 12,0 & 5,9 & 0,287 & 0,004 & Chn $>$ UK, Sp, Ger & 0,010 \\
\hline 9 & Weighted average only & 92,5 & 59,1 & 29,2 & 57,7 & 88,2 & 71,4 & 0,516 & 0,000 & Chn $>$ Aus, UK, Fr, Ger & 0,050 \\
\hline $\begin{array}{l}1 \\
0\end{array}$ & Proportional consolidation & 50,0 & 5,3 & 22,4 & 81,3 & 84,6 & 31,3 & 0,599 & 0,000 & Chn $>$ Aus, UK & 0,050 \\
\hline
\end{tabular}

Cramer's test found a significant correlation between countries and policy options at a p-value $<0.05$. This level of correlation was measured by Cramer's V per policy. A review of the test results suggests that the association is stronger for the "Focusing on net assets" (0.838) and "Indirect cash flow" (0.832) options, while it is lower, even if still fairly high, for the "Investment property at fair value" (0.638) and "Proportional consolidation" $(0.599)$ options.

The pairwise binomial test indicates which countries are more or less inclined to use certain policies compared to China. The tested hypotheses are described below. For each hypothesis, the null hypothesis means that there is no difference between China and the compared country. Rejection of the null hypothesis provides statistical evidence of a difference at a set level of significance.

H1: Chinese companies are more inclined than others to use a function-based income statement: Chinese companies are more inclined than other countries to record expenses by function. Article 104 of the ASBE ruled that expenses should be recorded by function, with costs divided into cost of goods sold, operating costs, general costs, and administrative and financial costs.

H2: Chinese companies are less inclined than others to use a version of financial positions: Chinese companies are less inclined than Australia and the UK to show "net assets". The matching Chinese accounting principle (ASBE 31) indeed stated that items presented in the balance sheet should be specified.

H3: Chinese companies are more inclined than others to use a direct method to calculate the operating cash flows: Chinese companies' propensity for using the direct method is significant only in comparison to Australia. The ASBE 31 principle required the use of the direct method, accompanied by a note showing the reconciliation of profit to net cash flow from operating activities using the indirect method. For this option, China's position is very similar to that of Continental European countries.

H4: Chinese companies are less likely than others to show dividends received as an operating activity: Chinese companies are less inclined than Australia and France to show dividends received as an operating activity. In Australia and France, the national GAAPs recorded dividends as an operating activity. Conversely, the ASBE 31 principle specified that the appropriate classification is "cash outflow from financing activities".

H5: Chinese companies are less likely than others to show interest paid as an operating activity: the ASBE 31 principle specified that interest paid should be recorded as "cash outflow from financing activities". The test found the most significant difference to be with Australia (in this case, the test rules out France, although French GAAP here is the same as Australia, i.e., interest paid shown as an operating activity; however, this may be due to the low number of observations).

H6: Chinese companies are less inclined than others to measure PPE at fair value: this assumption leads once again to placing Chinese companies closer to the Continental European scenario. The test finds that 
Chinese companies are less inclined than Australia and the UK to use fair value as a measurement of property, plant and equipment (PPE). In China, art. 3 of the standard - Fixed Assets (ASBE 4) only allowed the cost model, unlike IAS 16, which allows both cost and revaluation models. Only in Australia and the UK is the revaluation model freely allowed.

H7: Chinese companies are less inclined to measure investment property at fair value: this test leads once again to a similar assumption to that from test H4. Under Chinese law, the fair value model could not be used. The test shows significant results in comparison with Australia and the UK, where fair value was already used pre-IFRS.

H8: Chinese companies are less inclined than others to designate financial assets at fair value (the fair value option): Most of the analysed Chinese financial statements referred to 2005; at that time, the fair value option was not yet in force (effective for annual periods beginning on or after January 1, 2006 (Note 3)). In general terms, the use of fair value in China presents a "controversial story": under the regulation of 2001 (still in force in 2005/06), fair value was forbidden because the MOF considered that it could be used to manipulate earnings. It was allowed until 2001 and then again after the last ASBE reform in 2006.

H9: Chinese companies are more inclined than others to use a weighted average: Chinese companies are more inclined than any other country to use the weighted-average method. Standard-Inventories Art. 17 did not state any specific ban but gave free option to use any one of the following methods: FIFO, Moving Average Method, Weighted Average Method, Specific Identification Method, LIFO (suppressed by the 2006 ASBE reform). For a better understanding of this result, such figures should be cross-referenced to the Chinese tax requirements of the time (non retrievable).

H10: Chinese companies are more inclined to use the proportional consolidation method: the test found that Chinese companies are more inclined to use proportional consolidation than Australian or British companies, neither of which were allowed to use the proportional consolidation method pre-IFRS. In China, the proportionate consolidation method was the only method that could be used (changed by the 2006 ASBE reform, which issued the CAS 33 principle), similar to France (as opposed to Spain and Germany).

To summarise, a review of all pairwise binomial tests suggests that China is the most different from Australia ( 9 comparisons out of 10), followed by the UK (7 comparisons out of 10). The table below (Fig. 5) shows the results of each country analysed by Kvaal \& Nobes (2010) compared with China.

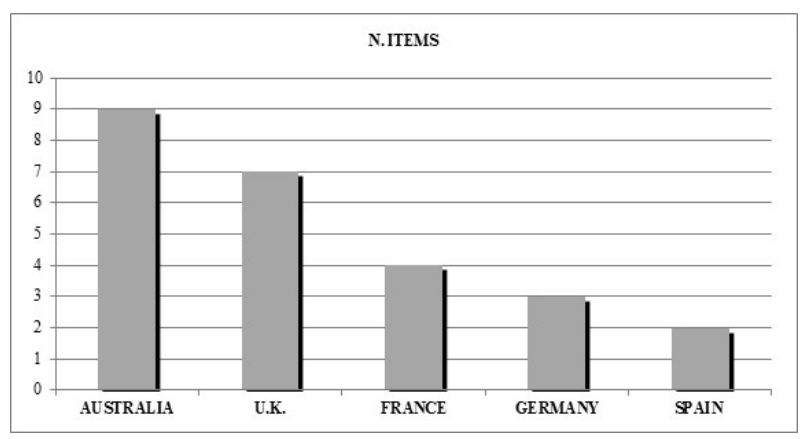

Figure 5. Binomial tests, comparison between countries

\subsection{Multivariate Analysis: Principal Component Analysis (PCA), Cluster Analysis and Multidimensional Scaling}

The purpose of these analyses is to test China's position within the classification system proposed by Nobes in 2011. The hypothesis is that China is closer to the Continental European group because the role of accounting is addressed more toward an audience of financial management and creditors.

The tests (Principal Component Analysis, Multidimensional Scaling and Cluster Analysis) aim to detect any cluster of countries that behaves similarly in terms of policies. This paper used Nobes's database (2011) for 13 IFRS policy choices. The countries considered with China are Australia, the UK, Germany, France, Spain, Holland, Italy and Sweden. We also analysed the data collected by Sarquis et al. for the BRICS. This study was conducted using Nobes's database and found some peculiarities in the emerging countries that differ from the standard Anglo and European country clusters; they therefore identified a new cluster, named the "Emerging Cluster". The accounting reports of the other countries covered by this survey (Russia, Brazil and South Africa) 
are for the financial year 2012, which, as mentioned by the authors, is a weakness of the analysis because the accounting reports in Nobes's database are for approximately 2008/2009.

China's records are still those for 2005/2006, as in the previous tests. Despite this time gap, which is a weakness of this analysis, no substantial difference was found in the IFRS principles, and the reduction of policy options from 16 (Kvaal \& Nobes 2010) to 13 (Nobes 2011) is, as explained by the author, a consequence of the decision to focus more on measurement than on presentation. The choice to use Nobes's database (Nobes 2011) instead of the database used in the chi-square and pairwise binomial tests (Kvaal and Nobes 2010) was dictated by the analyses covered by point 4 ), below, which consist of statistically processing the same figures plus the figures of other emerging countries (Brazil, South Africa and Russia), argued from the studies of Sarquis et al. (2014).

The purpose of this statistical analysis is to discover whether China belongs to the Continental European area, identified by Nobes (1998) as having "weak equity outsider financing and with a tax-and creditor-oriented accounting system".

Therefore, the hypotheses that arise from this goal are as follows:

\section{H11: In the enforcement of the IFRS, China belongs to the Continental European group.}

\section{H12: In the enforcement of the IFRS, China belongs to the new "Emerging Cluster".}

\subsubsection{Principal Component Analysis (PCA)}

PCA is a statistical procedure for reducing data size that uses an orthogonal transformation to convert a set of correlated variables into a set of linearly uncorrelated variables, called principal components. The principal components considered must be able to explain the variance between the objects of the study (in this case, countries) observed in the data set. Having identified the principal components, the approach then focuses on those that explain the greatest variance. In particular, it is common practice to select those that have eigenvalues greater than one.

In this case, four such components were identified, accounting for $85 \%$ of variance. The table of principal component scores for four synthetic dimensions shows some potential clusters that will be graphically easier to understand in the next analyses. Most importantly, the Anglo area (Australia and UK) comes first, with similar scores on component 1; Sweden is, instead, the only country that scores very high on component 2, and China scores high on component 4. Spain and Holland on the positive axis, Germany and Italy on the negative one, are more similar on component 3. Component 4 is most closely correlated to policy number 7), Indirect Cash Flow.

Table 7. Principal component scores

\begin{tabular}{lllll}
\hline Country & pca1 & pca2 & pca3 & pca4 \\
\hline Aus & 3,4439 & $-1,8538$ & $-0,2767$ & 1,5397 \\
UK & 3,0012 & $-0,9346$ & $-0,3982$ & $-1,6737$ \\
France & $-1,5457$ & 0,2137 & $-0,3725$ & $-0,4793$ \\
Spain & $-2,2119$ & $-2,2134$ & 1,8539 & $-1,2780$ \\
Germany & $-0,8152$ & $-0,2923$ & $-1,8433$ & $-0,3858$ \\
Netherlands & 0,4072 & 1,2939 & 1,9032 & 0,1323 \\
Italy & $-2,1707$ & 0,4732 & $-1,6720$ & 0,0351 \\
Sweden & 1,3415 & 3,4713 & 0,3348 & $-0,3867$ \\
China & $-1,4503$ & $-0,1580$ & 0,4709 & 2,4964 \\
\hline
\end{tabular}

The data collected by Sarquis et al. (2014) for Brazil, Russia and South Africa, included in Nobes's database (Nobes 2011), are considered with a view to discovering how China is placed within the earlier analysis.

Having identified the principal components, the approach then focuses on those that explain the greatest variance. In particular, it is common practice to select those that have eigenvalues greater than one. In this case, four such components were identified, accounting for $77 \%$ of variance; component 5 is not considered because the associated eigenvalue is approximately 1 . To interpret each component, we must compute the correlations between the original data for each variable and each principal component. For each country, principal component scores are calculated. Then, each country is assigned to the component it weighs heaviest on. 
Table 8. Principal component scores

\begin{tabular}{lllll}
\hline Country & pca1 & pca2 & pca3 & pca4 \\
\hline Aus & 4,4680 & $-0,5304$ & $-1,9760$ & $-0,0216$ \\
UK & 3,7560 & $-0,1494$ & 1,3298 & 1,0167 \\
France & $-1,1952$ & $-1,0489$ & 0,3197 & 0,2636 \\
Spain & $-0,8814$ & $-3,2784$ & 1,5939 & 0,1307 \\
Germany & $-0,4969$ & $-0,8714$ & $-0,3743$ & 1,5220 \\
Netherlands & 0,6386 & 0,4606 & 1,1656 & $-1,6835$ \\
Italy & $-1,6132$ & $-1,5062$ & $-0,1585$ & $-1,0460$ \\
Sweden & 0,4865 & 2,9630 & 1,2796 & $-1,0200$ \\
China & $-0,9934$ & $-0,8490$ & $-2,0218$ & $-1,3043$ \\
Brazil & $-2,0715$ & 1,5733 & $-0,5724$ & 1,6717 \\
Russia & $-1,0424$ & 1,5409 & 0,0317 & 0,9159 \\
South Africa & $-1,0550$ & 1,6957 & $-0,6172$ & $-0,4452$ \\
\hline
\end{tabular}

5.3.2) Multidimensional Scaling: Another analytical method is Multidimensional Scaling (MDS). It represents data as a two-dimensional cluster of points, offering a graphical representation of the distance between countries. This method was also used by Nobes (2011, 2013), Frank (1979) and D'Arcy (2001). According to Mardia's Goodness of Fit Measure, variation is explained by two such dimensions (measures based on classic metric MDS).

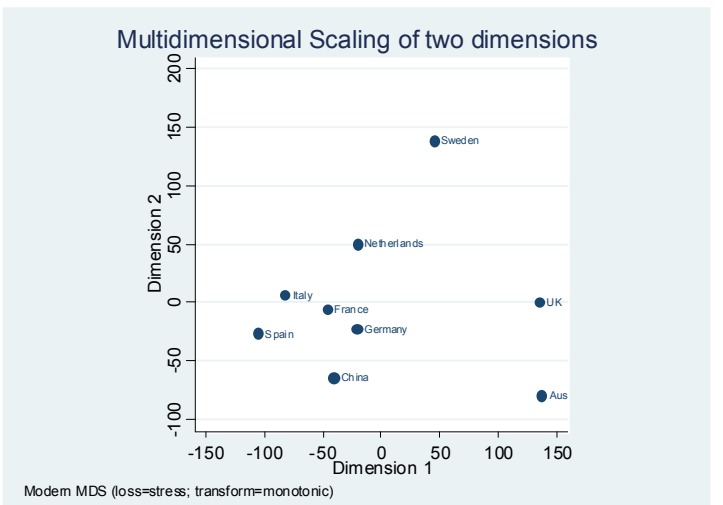

Figure 6. Multidimensional Scaling Non-Metric solution

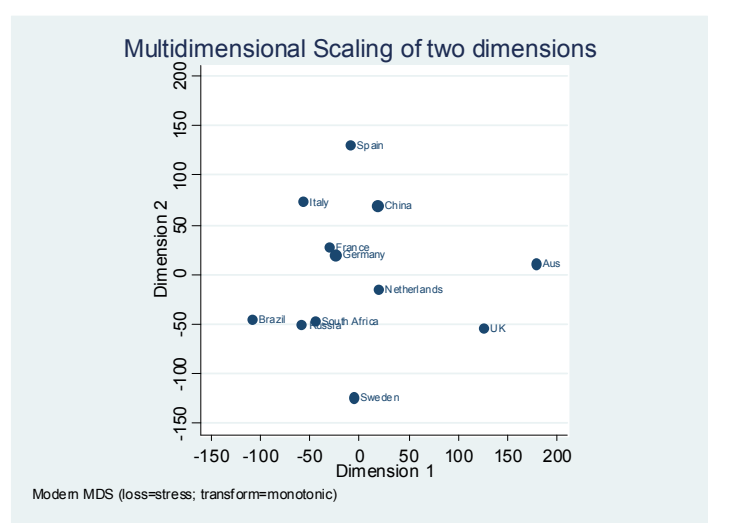

Figure 7. Multidimensional Scaling Non-Metric solution-BRIC data 
C) Cluster Analysis: This analysis, used by Nobes (1983, 2011), D’Arcy (2001) and Nobes \& Stadler (2013), identifies consistency in policies between each pair of countries using average linkage between groups. In this case, Germany and France are the most similar. The analysis then fuses the two into one unit and looks for the next nearest pairing, and so on. The result is shown in the figure. The vertical branching lines rise as each new country is added, showing increasing dissimilarity. In this case, Italy, China, the Netherlands and Spain are gradually added to Germany and France. Meanwhile, Australia and the UK form their own pair. Lastly, Sweden joins the fused Continental group.

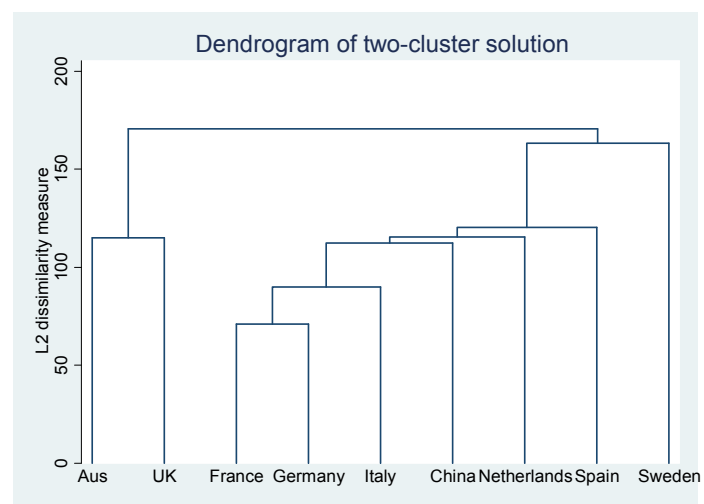

Figure 8. Cluster analysis

The vertical branching lines rise as each new country is added, showing increasing dissimilarity. As we can see, Australia and the UK form their own pair. The other countries appear to form a different cluster, which may be divided at a lower level of dissimilarity between a European and an Emerging Cluster. Based on this assumption, China's place is gradually added to France, Germany and Italy in the same place as in the cluster analysis at point 3), i.e., in the European Continental area, staying out of the Emerging Cluster area identified by Sarquis et al. (2014).

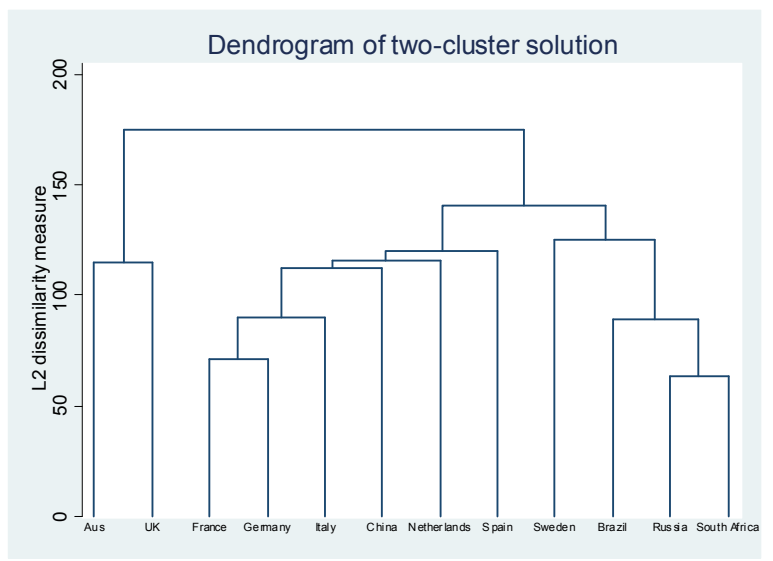

Figure 9. Cluster analysis - BRIC data

\section{Discussion}

Accounting is the tool through which companies elect, measure and disclose figures and information to all of their stakeholders. Differences in accounting languages make it difficult to understand the figures of companies based in different countries. International accounting studies have investigated the differences and similarities between the accounting systems of different countries and have found some macro areas, such as Anglo-Saxon and Continental European areas (Nobes 1983). After the issuance of IFRS, the participating countries expressed an interest in giving their accounting systems a more international outlook, thereby to fill the gaps resulting from 
the application of local GAAPs. However, despite the standardisation brought about by the IFRS, some differences still remain between different countries. Such differences occur because despite the international standards, the preparers are still local and therefore influenced by local accounting practices. Such differences can be empirically found in the choices made by preparers regarding IFRS policy options (Kvaal \& Nobes, 2010; 2012; Nobes, 2011; Nobes \& Stadler, 2013; Stadler \& Nobes, 2014). These differences, which are based on classes drawn up since the 1960s, lead us, once again, to find two separate groups: the Anglo and the Continental European. The former are more focused on shareholders, and the latter are more focused on taxes and creditors.

Such studies do not address the role of emerging markets for a number of reasons: the historic backwardness of such countries, language problems, or accounting systems that are completely different from those elsewhere and challenging to understand. China, an emerging market that is now an established global power, is an interesting case study because it has taken a different path than other emerging countries, such as Brazil, Russia and South Africa, which have fully converged to IFRS. After years of isolation, in 1978, China implemented a number of reforms to develop its economy and open it up to the rest of the world. The latest reform of accountancy occurred in 2006, when the local Chinese principles were rated as substantially converged to IFRS. Prior to this reform, however, for a period of time, those Chinese companies that issued shares purchasable by foreign investors were compelled to draw up their accounting reports according to IFRS principles. This paper focused on a review of the choices made by Chinese preparers in the enforcement of the IFRS policy options as of that date (2005/2006) and on a classification of China within the existing studies (Kvaal \& Nobes 2010, Nobes 2011, Sarquis et al. 2014). The level of influence of the local GAAP was analysed, and the choices made by China were compared with the choices made by other countries.

A statistical analysis found that, within Nobes's classification (2011), China is closer to the Continental European countries than to the Anglo ones. This finding is corroborated by a historical review of accounting in China, a country where most companies are owned by the State, where accounting is tax oriented and have still has immature capital markets (as of this date). The outcome differs from that of the analysis conducted by Nobes \& Stadler in 2013, which looked into the accounting reports of Chinese companies listed on the Hong Kong Stock Exchange and found the Chinese system to be closer to the UK area. As also mentioned by those authors, until 1997, British influence was still deeply felt in Hong Kong. This is an important finding because when we look at the companies listed on Mainland China's Stock Exchanges, the result is different. In fact, as noted by the authors, colonialism offers an important perspective for understanding local accounting. Despite its limits, mainly due to the small size of the sample and the impossibility of testing Chinese changes in policy options, this paper makes a further contribution to the literature by showing that despite the standardisation brought about by the IFRS, international differences in accounting depend on the local accounting systems as well as on the legal and financial systems of each country.

This research, despite the limitations described above, represents a further contribution to the analysis of the application of IFRS in the world and then the process of harmonization that they intend to achieve. Considering the "substantial convergence" of the PRC GAAP and IFRS, as determined by the IASB in 2006, it would be interesting, as a further step of this research extend the analysis to the latest data, in particular for the evaluation of certain key areas related to Chinese accounting tradition (for example, use of evaluation at fair value).

\section{Acknowledgements}

The authors are grateful, for comments and suggestions to Professor Christopher Nobes.

The authors would like to acknowledge the session chair and all participants at the $38^{\text {th }}$ Annual Congress European Accounting Association (EAA) for the useful and interesting suggestions and comments

\section{References}

Aiken, M., \& Lu, W. (1993a). Chinese Government Accounting: Historical Perspective and Current Practice. British Accounting Review, 25, 109-129. https://doi.org/10.1006/bare.1993.1012

Aiken, M., \& Lu, W. (1993b). Historical Instances of Innovative Accounting Practices in the Chinese Dynasties and Beyond. The Accounting Historians Journal, 20(3), 163-186.

Aiken, M., \& Lu, W. (1998). The Evolution of Bookkeeping in China: Integrating Historical Trends with Western Influences. Abacus, 34(1), 140-162. https://doi.org/10.1111/1467-6281.00026

American Accounting Association. (1966). A Statement of Basic Accounting Theory. Evanston: American Accounting Association, Illinois. 
American Accounting Association. (1977). Report of the American Accounting Association Committee on International accounting operations and education (1975-1976). The Accounting Review, (52).

Ball, R., (2006). International Financial Reporting Standards (IFRS): Pros and cons for investors. Accounting and Business Research, International Accounting Policy Forum, 38(14), 5-27. https://doi.org/10.1080/00014788.2006.9730040

Baydoun, N., \& Willet, R. (1995). Cultural Relevance of Western Accounting System to Developing Countries. Abacus, 31(1), 276-299. https://doi.org/10.1111/j.1467-6281.1995.tb00355.x

Bromwich, M., \& Wang, G. (1991). Management Accounting in China: A Current Evaluation. The International Journal of Accounting, 26, 51-66.

Chen, J. J., \& Zhang, H. (2010). The Impact of Regulatory Enforcement and Audit upon IFRS Compliance-Evidence from China. European Accounting Review, 19(4), 665-692. https://doi.org/10.1080/09638180903384684

Chen, J. P. C., Gul, A. F., \& Su, X. (1999). A Comparison of Reported Earnings Under Chinese GAAP vs. IAS: Evidence from the Shanghai Stock Exchange. Accounting Horizons, 13(2), 91-111. https://doi.org/10.2308/acch.1999.13.2.91

Chen, S., Sun, Z., \& Wang, Y. (2002). Evidence from China on Whether Harmonized Accounting Standards Harmonize Accounting Practices. Accounting Horizons, 16(3), 183-197. https://doi.org/10.2308/acch.2002.16.3.183

Choi, F. D. S., \& Mueller, G. G. (1992). International Accounting. Englewood Cliffs: Prentice-Hall International Editions.

Chow, L. M., Chau, G. K., \& Gray, S. J. (1995). Accounting Reforms in China: Cultural Constraints on Implementation and Development. Accounting and Business Research, 26(1), 29-49. https://doi.org/10.1080/00014788.1995.9729497

D'Arcy, A. (2001). Accounting classification and the international harmonization debate-an empirical $\begin{array}{lllll}\text { investigation. Accounting, Organization and Society, 26(4), 327-349. } & \text {. }\end{array}$ https://doi.org/10.1016/S0361-3682(00)00036-2

Da Costa R.C., Bourgeois J.C., \& Lawson W.M. (1978). A Classification of International Financial Accounting Practices. The International Journal of Accounting, 13(2), 73-85.

Di Pietra, R. (2000). Ragioneria Internazionale e “armonia contabile”. Padova: Cedam.

Doupnik, T. S., \& Salter, S. B. (1993). An Empirical Test of Judgmental International Classification of Financial Reporting Practices. Journal of International Business Studies, 24(1), 41-59. https://doi.org/10.1057/palgrave.jibs.8490224

Erikson, D., Esplin, A., \& Maines, L. A. (2009). One world - One accounting. Business Horizons, 52, 531-537. https://doi.org/10.1016/j.bushor.2009.06.006

Ezzamel, M., \& Xiao, J. Z. (2007). Regulating Accounting in Foreign Invested Firms in China: from Mao to Deng. The Institute of Chartered Accountants of Scotland.

Ezzamel, M., Xiao, J. Z., \& Pan, A. (2007). Political ideology and accounting regulation in China. Accounting Organizations and Society, 32, 669-700. https://doi.org/10.1016/j.aos.2006.09.008

Foo, D., Liu, B., \& Davey, H. (2009). Financial reporting gaps and value relevance: Chinese Accounting and International Accounting Standards post-2001. Asian Academy of Management Journal of Accounting and Finance, 5(2), 55-76.

Frank, W. G. (1979). An Empirical Analysis of International Accounting Principles. Journal of Accounting Research, 17(2), 593-605. https://doi.org/10.2307/2490520

Fu, P. (1971). Governmental Accounting in China During the Chou Dynasty (1122 B.C.-256 B.C.). Journal of Accounting Research, 9(1), 40-51. https://doi.org/10.2307/2490201

Gao, S. S., \& Handley-Schachler, M. (2003). The influences of Confucianism, Feng Shui and Buddhism in Chinese accounting history. Accounting, Business \& Financial History, 13(1), 41-68. https://doi.org/10.1080/09585200210164566d 
Graham, L. E., \& Li, C. (1997). Cultural and Economic Influences on Current Accounting Standards in the People's Republic of China. The International Journal of Accounting, 32(3), 247-278. https://doi.org/10.1016/S0020-7063(97)90011-X

Gray, S. I. (1988). Towards a theory of cultural influence on the development of accounting system internationally, Abacus, 24(1), 1-15. https://doi.org/10.1111/j.1467-6281.1988.tb00200.x

Harrison, G. L., \& McKinnon, J. L. (1986). Cultural and Accounting Change: A New Perspective on Corporate Reporting Regulation and Accounting Policy Formulation. Accounting, Organization and Society, 11(3), 233-252. https://doi.org/10.1016/0361-3682(86)90023-1

Hatfield, H. R. (1966). Some Variations in Accounting Practice in England, France, Germany and the United States. Journal of Accounting Research, 307-321. https://doi.org/10.2307/2489952

Heng, L. C. C., \& Noronha, C. (2011). The impact of the new Accounting Standard for Business Enterprises (ASBE) on financial results of mainland Chinese listed companies. Adavances in Accounting, incorporated Advances in International Accounting, 27, 156-165.

Hoefstede, G., \& Bond, M. H. (1988). The Confucius connection: from cultural roots to economic growth. Organizational Dynamics, 16, 5-21. https://doi.org/10.1016/0090-2616(88)90009-5

Hofstede, G. (1980). Culture's Consequences, Sage Publications.

Jun Lin, Z. (1992). Chinese Double-Entry Bookkeeping before the Nineteenth Century. The Accounting Historians Journal, 19(2), 103-122.

Kvaal, E., \& Nobes, C. W. (2010). International differences in IFRS policy choice: A research note. Accounting and Business Research, 40(2), 173-187. https://doi.org/10.1080/00014788.2010.9663390

Kvaal, E., \& Nobes, C. W. (2012). IFRS Policy Changes and the Continuation of National Patterns of IFRS Practice. European Accounting Review, 21(2), 343-371. https://doi.org/10.1080/09638180.2011.611236

Lefebvre, C., \& Lin, L. (1990). Internationalization of Financial Accounting Standards in the People's Republic of China. The International Journal of Accounting, 25, 170-183.

Lin, Z. J., \& Wang, L. (2001). Financial disclosure and accounting harmonization: Cases of three listed companies in China. Managerial Auditing Journal, 16(5), 263-273. https://doi.org/10.1108/02686900110392913

Liu, C., Yao, L. J., Hu, N., \& Liu, L. (2011). The impact of IFRS on Accounting Quality in a Regulated Market: An Empirical Study of China. Journal of Accounting Auditing\& Finance, 26(4), 659-676. https://doi.org/10.1177/0148558X11409164

Liu, Y. (2010). The Study of Application Status of Fair Value Accounting in China. International Journal of Business and Management, 5(9), 155-158. https://doi.org/10.5539/ijbm.v5n9p155

Mueller, G. G. (1967). International Accounting. New York: Macmillan.

Nobes, C. W. (1981). An Empirical Analysis of International Accounting Principles-A comment. Journal of Accounting Research, 19(1), 268-270. https://doi.org/10.2307/2490974

Nobes, C. W. (1983). A Judgmental International Classification of Financial Reporting Practises. Journal of Business Finance \& Accounting, 10(1), 1-19. https://doi.org/10.1111/j.1468-5957.1983.tb00409.x

Nobes, C. W. (1998). Towards a General Model of the Reasons for International Differences in Financial Reporting. Abacus, 34(2), 162-187. https://doi.org/10.1111/1467-6281.00028

Nobes, C. W. (2006). The survival of international differences under IFRS: towards a research agenda. Accounting and Business Research, 36(3), 233-245. https://doi.org/10.1080/00014788.2006.9730023

Nobes, C. W. (2011). IFRS Practices and Persistence of Accounting System Classification. Abacus, 47(3), 267-283. https://doi.org/10.1111/j.1467-6281.2011.00341.x

Nobes, C. W. (2013). The continued survival of international differences under IFRS. Accounting and Business Research, 43(2), 83-111. https://doi.org/10.1080/00014788.2013.770644

Nobes, C. W., \& Parker, R. (2012). Comparative International Accounting (12th ed.). Harlow: Pearson.

Nobes, C. W., \& Stadler, C. (2013). How arbitrary are international accounting classifications? Lesson from centuries of classifying in many disciplines and experiments with IFRS data. Accounting, Organizations and Society, 38, 573-595. https://doi.org/10.1016/j.aos.2013.10.001 
Olesen, K., \& Cheng, F. (2011). Convergence of Accounting Standards Does Not Always Lead to Convergence of Accounting Practises: The Case of China. Asian Journal of Business and Accounting, 4(1), 23-58.

Peng, S., Tondkar, R. H., Van Der Laan Smith. J., \& Harless, D. W. (2008). Does Convergence of Accounting Standards Lead to the Convergence of Accounting Practices? A Study form China. The International Journal of Accounting, 43, 448-468. https://doi.org/10.1016/j.intacc.2008.09.009

Ren, M. C., Alexander, D., \& Kedslie, M. (1995).The trend of accounting in China. Issued and environment. In Blake, J. \& Gao, S., Perspectives on accounting and finance in China. London: Routledge.

Sarquis, R. W, Luccas, R. G., Lourenco, I., \& Dalmácio, F. Z. (2014). IFRS accounting systems' classification: a new emerging cluster. Working Paper. European Accounting Association Annual Congress, Tallinn. Available at http://papers.ssrn.com

Scapens, R. W., \& Hao, Z. (1995). Chinese accounting reform. Reasons and effects. In Blake, J. \& Gao, S. (Eds.), Perspectives on accounting and finance in China. London: Routledge.

Seidler J. J. (1967). International Accounting-The Ultimate Theory Course. The Accounting Review, 775-781.

Shoenthal, E. R. (1989). Classification of Accounting Systems using Competencies as a Discriminating Variable: A Great Britain-United States Study. Journal of Business Finance \& Accounting, 16(4), 549-563. https://doi.org/10.1111/j.1468-5957.1989.tb00037.x

Solas, C., \& Ayhan, S. (2007). The Historical Evolution of Accounting in China: The Effects of Culture. Spanish Journal of Accounting History, 7, 146-173.

Stadler, C., \& Nobes, C. W. (2014). The Influence of Country, Industry and Topic Factors on IFRS Policy Choice. Abacus, 50(4), 386-421. https://doi.org/10.1111/abac.12035

Tang, Y. (2000). Bumpy Road Leading to Internationalization: a Review of Accounting Development in China. Accounting Horizons, 14(1), 93-102. https://doi.org/10.2308/acch.2000.14.1.93

Walton, P., Haller, A., \& Raffournier, B. (1998). International Accounting. London: International Thomson Business Press.

Xiang, B. (1998). Institutional Factors Influencing China's Accounting Reforms and Standards. Accounting Horizons, 105-119.

Xiao, J. Z., Weetman, P., \& Sun, M., (2004). Political Influence and Coexistence of a Uniform Accounting System and Accounting Standards: Recent Developments in China. Abacus, 40(2), 193-218. https://doi.org/10.1111/j.1467-6281.2004.00151.x

Xiao, Z., \& Pan, A. (1997).Developing Accounting Standards on the Basis of a Conceptual Framework by Chinese Government. The International Journal of Accounting, 32(3), 279-299. https://doi.org/10.1016/S0020-7063(97)90012-1

Yip, R. W. Y., \& Young, D. (2012). Does Mandatory IFRS Adoption Improve Information Comparability? The Accounting Review, 87(5), 1767-1789. https://doi.org/10.2308/accr-50192

Zhou, Z. H. (1988). Chinese Accounting Systems and Practices. Accounting Organizations and Society, 13(2), 207-224. https://doi.org/10.1016/0361-3682(88)90045-1

\section{Notes}

Note 1. BRICS Countries are: Brazil, Russia, India, China and South Africa.

Note 2. This situation is already identified in the 1977 report of the American Accounting Association following the 1975 study of the AAA Committee on Accounting in Developing Countries. Report of the American Accounting Association Committee on international accounting operations and education (1975-1976). The Accounting Review, n.52.

Note 3. Accounting Standards for Business Enterprises.

Note 4. Chinese Local Standards.

Note 5. Chinese Local Standards.

Note 6. International Financial Reporting Standards.

Note 7. See the IFRS Foundation's China fact sheet, www.ifrs.org 
Note 8. Chinese companies may issue two types of shares: A shares, which can only be bought by Chinese investors, and B shares, which can be bought by foreign investors. B share companies were required to present their financial statements using IFRS. They had to be audited by international accounting firms (Big 5) because the participants in the B share market were overseas investors.

Note 9. South Africa completed its adherence to IFRS principles in 2005, while Brazil did so in 2010, and Russia in 2012.

Note 10. Reasons previously proposed for international accounting differences are as follows: Nature of business ownership and financing system; Colonial inheritance; Invasions; Taxation; Inflation; Level of education; Age and size of accountancy profession; Stage of economic development; Legal system; Culture; History; Geography; Language; Influence of theory; Political system; Social climate; Religion; Accidents. Nobes, C.W. (1998). Towards a General Model of the Reasons for International Differences in Financial Reporting. Abacus, Vol. 34, No. 2, p. 163.

Note 11. "The fundamental reason for being sceptical about uniformity of implementation in practice is that the incentives of preparers (managers) and enforcers (auditors, courts, regulators, boards, block shareholders, politicians, analysts, rating agencies, the press) remain primarily local'. Ball, (2006) International Financial Reporting Standards (IFRS): pros and cons for investors. Accounting and Business Research, International Accounting Policy Forum, Vol. 38, No. 14, p.15.

Note 12. Chinese Local Standards.

Note 13. Kvaal and Nobes's sample also included financial statements referring to the period 2005-2006.

\section{Copyrights}

Copyright for this article is retained by the author(s), with first publication rights granted to the journal.

This is an open-access article distributed under the terms and conditions of the Creative Commons Attribution license (http://creativecommons.org/licenses/by/4.0/). 